\title{
Millä ehdoilla korkea-asteen täydennyskoulutusta?
}

Aikuiskasvatuksen tärkein kysymys on, mitä opetetaan. Oikea, olennaiseen osuva tieto auttaa oppilaita ymmärtämään paremmin ja toimimaan viisaammin. Se virittää oppimaan edelleen. Kirvoittaakseen oppilaissa kehitystä, opetuksen tulee seurata tieteen kärkitietoa ja edistyneintä teoreettista ajattelua.

Tieteellisen tiedon uusiutumisnopeus on jatkuvasti kiihtynyt. Käsitys asioista saattaa monilla aloilla muuttua perusteitaan myöten alle kymmenessä vuodessa. Yhtä lyhyessä ajassa syntyy kokonaan uusia merkittäviä tiedon ja tekniikan aloja. Yhteiskunta on lisäksi päivittäisessä toiminnassaan yhä monimutkaisemmin riippuvainen tieteestä. Monimutkaisia käytännön ongelmia ei voida ymmärtäà ei$k \ddot{a}$ ratkaista ilman teoreettista tietoa.

Etäisyys tieteellisen ajattelun kärjen ja aikuiskasvatuksessa välitettävien käsitysten välillä kasvaa entisestään ellei asiaan kiinnitetä vakavaa huomiota. Yksi ratkaisu ongelmaan on korkeakoulujen täydennyskoulutuksen tehostaminen. Siitä on meillä keskusteltu jo pitkädn. Ensimmäisenä kiinnitettiin huomiota opettajien täydennyskoulutukseen. Systemaattisen täydennyskoulutustoiminnan käynnistämistä ovat kuitenkin hidastaneet sekä valtiontalouden ongelmat että korkeakoulujen perusopetuksen uudistaminen. Laajeneva täydennyskoulutus voi luoda uudenlaisia yhteyksiä korkeakoulujen tieteellisten asiantuntijoiden ja aikuiskasvatuksen kentän välille. Alusta pitäen tulisi pyrkiä siihen, että nämä yhteydet johtavat pitkäjänteiseen, yhteiseen tutkimus- ja kehittämistyöhön, jossa aikuiskasvattajat eivät ole vain uuden tiedon vastaanottajia, vaan osallistuvat myös sen tuottamiseen yhdessä yliopistojen tutkijoiden kanssa.

Professori Martti Takalan johtama täydennyskoulutustoimikunta teki vuonna 1976 suunnitelman korkeakoulujen täydennyskoulutuksen asteittaiseksi kehittämiseksi. Suunnitelman mukaan vuodet 1978-81 olisivat täydennyskoulutuksen käynnistämistyön aikaa. Koulutuksen aktiivi kehittäminen tapahtuisi vuosina 1982-1985. Vuodesta 1986 alkaen täydennyskoulutus olisi vakiintunut osa korkeakoulujen toimintaa. Kehitys on pädpiirteittäin noudattanut tätḋ toimikunnan alun pitàen varovaista aikataulua. 1970-luvun aikana korkeakoulut ja yksittaiset tiedekunnat laativat suunnitelmia tàydennyskoulutuksen järjestämisestä. Opetusministeriön tänd̆ vuonna laatimaan korkeakoulujen kehittämissuunnitelmaan vuosiksi 1984-1986 sisältyy erillinen luku täydennyskoulutuksen kehittämisestä. Tuota suunnitelmaa voisi ehkä pitäd täydennyskoulutuksen aktiivisen kehittämisen linjanmäärityksenä. 
Täydennyskoulutustoimikunta korosti mietinnössaddn, ettd tàydennyskoulutus tulee sovittaa korkeakoulun antamaan peruskoulutukseen niin, ettd syntyy mielekkditd jatkuvan koulutuksen ohjelmia. Olennaisen osan täydennyskoulutusta muodostaisivat toimikunnan mukaan laajat täydennyskoulutusohjelmat, joiden suunnittelusta vastaisivat tieteelliset laitokset tai monitieteelliset suunnitteluelimet. Korkeakoulujen tulisi myös tàdennyskoulutuksessa mietinnön mukaan säilyttäd itsendisyytensä valtion keskushallintoon ja ulkopuolisiin tahoihin nähden. Tälä pohjalta täydennyskoulutuksen tulisi palvella yhteiskunnan eri toimintojen kehittamista. Taydennyskoulutuksen tarvitsijoista tulisi mietinnön mukaan asettaa etusijalle mm. henkilöt, joilla on keskeinen asema tiedon vallittamisessä. Aikuiskasvattajat kuuluvat epdilemättä tähän ryhmänn.

Korkeakoulujen täydennyskoulutuksen tähänastinen kehitys on ollut hajanaista eikd ole kaikin osin noudattanut taydennyskoulutustoimikunnan märittelemid suuntaviivoja. Opetusministeriön laatima kehittämissuunnitelma näyttä nyt kuitenkin vahvistavan monia tadydennyskoulutustoimikunnan esittamista peruslinjoista. Tapa, jolla tadydennyskoulutus tulevaisuudessa aiotaan rahoittaa ei kuitenkaan tàysin vastaa korkeakoulujen itsendisyyden periaatetta.

Kehittdmissuunnitelmassa lahdetadn siitä, ettà tàydennyskoulutus on padaasiallisesti maksullista palvelutoimintaa. Täydennyskoulutusta voivat käytännössä tilata vain viranomaiset ja varakkaat työnantajat. Nämä tuskin tilaavat koulutusta, joka ei ole sopusoinnussa tilaajan ajattelutavan ja padamädrien kanssa, olipa kurssin sisalttö tieteellisesti kuinka pätevd tahansa. Tilauskurssien ohella korkeakoulut voisivat jarjestäd maksullisia kursseja. Kurssikustannusten taysimadarainen periminen osanottajilta suosii niitd, jotka osallistuvat koulutukseen työnantajansa kustantamina. Se saattaa tehdä vaikeaksi tadydennyskoulutuksen hankkimisen niille, jotka eivadt tallaista tukea saa. Maksullisuus vähentäd myös korkeakoulujen mahdollisuuksia itsendisesti suunnata tàdennyskoulutusta.

Jotta korkeakoulut voisivat välittḋd vapaasti tieteellista tietoutta täydennyskoulutuksen avulla ja opettaa myös sellaisia asioita, jotka eivat vastaa vallitsevaa ajattelutapaa, niilld tulee olla mahdollisuus kaynnistä tadydennyskoulutusta myös omin varoin. 